Proc. Indian Acad. Sci. (Earth Planet. Sci.), Vol. 105, No. 2, June 1996, pp. 119-129.

(C) Printed in India.

\title{
Oxygen and carbon stable isotope studies on Globorotalia menardii from Pleistocene DSDP Cores in northern Indian Ocean and their paleoclimatic and paleoceanographic implications
}

\author{
ASHISH SARKAR ${ }^{1}$, ASIT K GUHA ${ }^{1}$ and \\ SUPRIYO CHAKRABORTY ${ }^{2}$ \\ ${ }^{1}$ Department of Geology and Geophysics, Indian Institute of Technology, Kharagpur \\ 721302 , India \\ ${ }_{2}^{2}$ Physical Research Laboratory, Ahmedabad 380009 , India
}

MS received 8 November 1995; revised 23 February 1996

\begin{abstract}
Stable isotope ratios of oxygen $\left(\delta^{18} \mathrm{O}\right)$ and carbon $\left(\delta^{13} \mathrm{C}\right)$ in tests of Globorotalia menardii from samples at $25 \mathrm{~cm}$ intervals of top $900 \mathrm{~cm}$ cores, representing different thicknesses of the Pleistocene, from DSDP Sites 219,220 and 241 in the northern Indian Ocean have been measured. Based on the $\delta^{18} \mathrm{O}$ stratigraphy, glacial and interglacial phases during the Pleistocene have been recognized, which are in good agreement with the standard Quaternary planktonic foraminiferal/climatic zones i.e., Ericson zones at these sites, based on G. menardii abundances. The GIA (glacial interglacial amplitude) at Sites 241, 219 and 220 are of the order of $1.2,1.4$ and $1.9 \%$ respectively. The last glacial and interglacial maxima (18 ka BP and $125 \mathrm{ka}$ BP respectively) could be identified in DSDP Cores 241, and 219 with some precision. 'Isotopic ages' could be assigned to the different levels of these core sections based on the correlation of $\delta^{18} \mathrm{O}$ record from these sites with the SPECMAP record (Imbrie et al 1984). Changes in sediment accumulation rates at different levels of the Pleistocene have been worked out on the basis of changes in oxygen isotopic ratio.

Oscillations in $\delta^{13} \mathrm{C}$ stratigraphy at Site 241 indicated southwest monsoon induced increase in upwelling and productivity during warmer periods. At Sites 219 and 220, variations in the $\delta^{13} \mathrm{C}$ record were due to the mixing of bottom water.
\end{abstract}

Keywords. Quaternary; stratigraphy; Ericson zones; glacial-interglacial amplitude (GIA); last glacial maxima (LGM); upwelling; stable isotope.

\section{Introduction}

Changes in temperature during the Pleistocene led to the occurrence of a number of major and minor glacial and interglacial phases on the earth. These paleoclimatic events left their signatures on oceanic biotal assemblages. Planktonic foraminifera secrete calcareous tests, the carbon and oxygen of which are in isotopic equilibrium with the surrounding water, i.e., they incorporate both isotopes of oxygen and carbon into the carbonate of their tests in the definite proportions relative to those present in the sea water and ocean bicarbonate. The relative abundance of oxygen isotopes, dependent mainly on water temperature at the time of formation of the test, remains unchanged through geologic time till the present day (Bowen 1966; Boersma 1978; Erez and Luz 1983). Similarly the stable carbon isotope ratio incorporated in the foraminiferal carbonate mainly depends on productivity and upwelling and to some extent on the input of organic carbon (Kennett 1986).

Stable isotopes of foraminiferal shells have been successfully used to record the late Neogene climatic fluctuations in northern Indian Ocean by a number of researchers (Prell 1978; Prell et al 1980; Prell and Curry 1981; Prell and Van Campo 1986; Prell and 
Kutzbach 1987; Prell and Niitsuma 1988; Gupta and Srinivasan 1990; Sarkar et al 1990; Srinivasan and Chaturvedi 1990; Srinivasan and Singh 1991; Singh and Srinivasan 1993 and Ahmad and Labeyrie 1994).

With an aim to establish stable isotope stratigraphy (both oxygen and carbon isotopes), the top $900 \mathrm{~cm}$ core from DSDP Sites 219, 220 and 241 were selected (figure 1). Based on the different sedimentation rates (Simpson et al 1974; Whitmarsh et al 1974), the core sections studied at different sites represent variable time span. Analyses of $\delta^{18} \mathrm{O}$ and $\delta^{13} \mathrm{C}$ were carried out on Globorotalia menardii tests from samples at $25 \mathrm{~cm}$ intervals of the above cores. The presence of voids and some deformation during coring at some levels in these cores prevents working with samples at a closer interval. The unevenness of sample spacing at some levels has been adjusted by using the cubic spline interpolation method. Though $G$. menardii is a deep-dwelling planktonic foraminifer species (Emiliani 1954, 1966), tests of the same were chosen for the isotopic analysis, since (a) they belong to the most common species in the present assemblages at all sites; (b) they are the most significant climatic indicators in equatorial and mid-latitude waters (Ericson et al 1964) and (c) they are least affected by dissolution (Berger 1968). Furthermore, based on fluctuations in the abundance of G. menardii, standard Quaternary planktonic foraminiferal/climatic zones (Ericson et al 1961; Ericson and Wollin 1968), have been delineated at DSDP Sites 219, 220 and 241 in northern Indian Ocean (Guha and Sarkar 1990; Sarkar 1991). These zones (R to $\mathrm{Z}$ upwards) at different sites have been compared with stable isotope stratigraphy.

\section{Description of sites}

The location of sites studied is shown in figure 1. Additional relevant information is presented in table 1 . Lithology of all the three sites is chiefly detrital clay rich

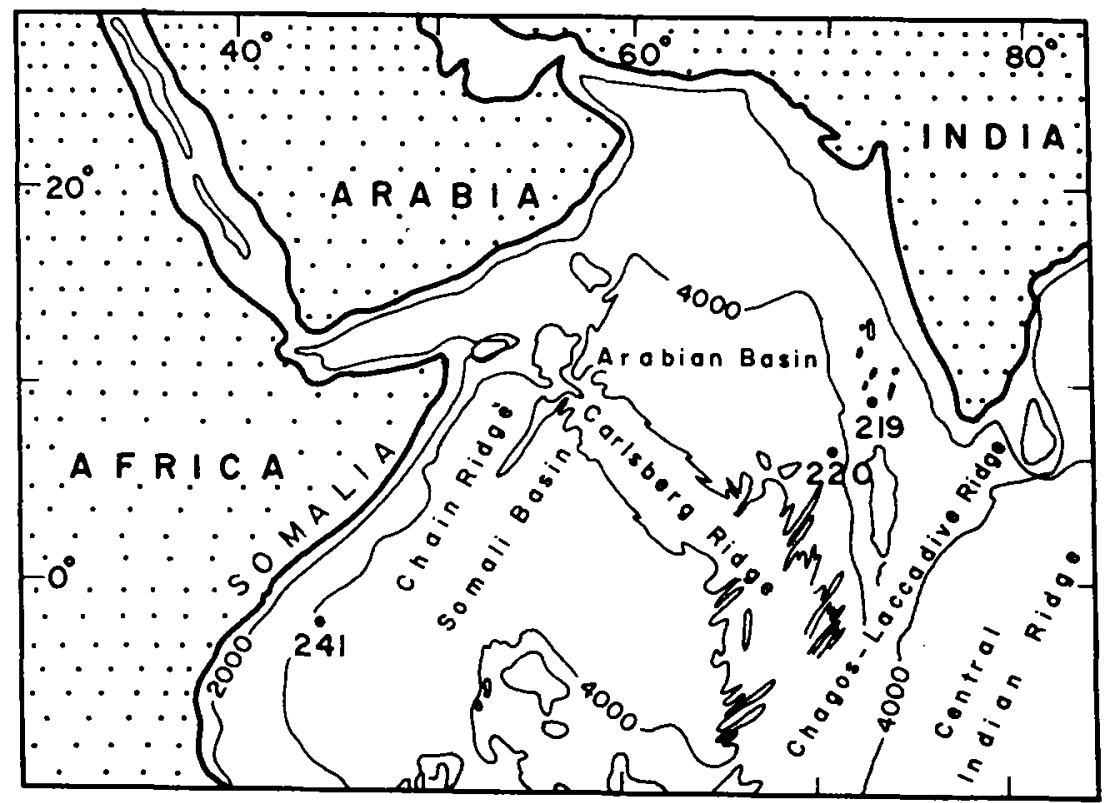

Figure 1. Map of northern Indian Ocean showing locations of DSDP Sites 219, 220 and 241. 
Table 1. Information on DSDP Sites 219, 220 and 241 (Source: Initial reports of the DSDP Vols. 23 and 25).

\begin{tabular}{llll}
\hline & Site 219 & \multicolumn{1}{c}{ Site 220} & \multicolumn{1}{c}{ Site 241} \\
\hline Latitude & $9^{\circ} 1 \cdot 75^{\prime} \mathrm{N}$ & $6^{\circ} 30 \cdot 97^{\prime} \mathrm{N}$ & $2^{\circ} 22 \cdot 24^{\prime} \mathrm{S}$ \\
Longitude & $72^{\circ} 52 \cdot 67^{\prime} \mathrm{E}$ & $70^{\circ} 59 \cdot 02^{\prime} \mathrm{E}$ & $44^{\circ} 40 \cdot 77^{\prime} \mathrm{E}$ \\
Water depth & $1764 \mathrm{~m}$ & $4036 \mathrm{~m}$ & $4054 \mathrm{~m}$ \\
$\mathrm{CaCO}_{3}$ (Avg.) & $65 \%$ & $58 \%$ & $70 \%$ \\
Sedimentation rate & $14 \mathrm{~m} / \mathrm{Ma}$ & $7 \mathrm{~m} / \mathrm{Ma}$ & $40 \mathrm{~m} / \mathrm{Ma}$ \\
$\quad$ (Avg.) & & & \\
Salinity (Pore water) & $\sim 36 \%$ & $\sim 35 \cdot 2 \%$ & $34 \cdot 9-35 \cdot 2 \%$ \\
\hline
\end{tabular}

nano-ooze. Foraminifera constitute a substantial part of the studied cores and are well preserved. The pore-water salinity at individual core sections varies within narrow limits, mostly around $1 \%$ (Whitmarsh et al 1974; Simpson et al 1974).

\section{Experimental methods}

Each sediment sample (about $1 \mathrm{gm}$ ) was boiled gently in calgon solution and washed with distilled water and passed through 0.4 and $0.25 \mathrm{~mm}$ sieves. The residue retained by the $0.25 \mathrm{~mm}$ sieve was further cleaned in an ultrasonic cleaner. The material was then dried in an oven at about $100^{\circ} \mathrm{C}$. Depending upon the size 10 to 15 tests of $G$. menardii, weighing about $1 \mathrm{mg}$, were taken in a small reaction tube. The tests were slightly crushed and washed with distilled water in an ultrasonic cleaner to remove any foreign material present within the test. The crushed tests were then dried and pulverized in an agate mortar.

The reaction tube with pulverized material in it was placed in the reaction chamber of the on-line $\mathrm{CO}_{2}$ extraction system for isotopic analysis. The sample was treated with $100 \%$ phosphoric acid at $50^{\circ} \mathrm{C}$. The carbon dioxide thus produced was analysed in a VG Micromass 602D Mass Spectrometer for carbon and oxygen isotopes with a precision of $\pm 0.07 \%$ based on a working standard (Chakraborty 1993).

\section{Results}

The results of the depth-wise stable isotope analysis are given in table 2 and plotted in figures 2 to 4 . The trends of individual plots are discussed separately. Since Site 241 recorded the highest sedimentation rate (cf. table 1), it is described first followed by Site 219 and Site 220.

\subsection{Core 241}

4.1.1 Oxygen isotopes: There are different cycles in the distribution of $\delta^{18} \mathrm{O}$ (figure 2) with an average value of $0.48 \%$, the maximum and minimum being 1.00 and $-0.3 \%$ respectively. The curve at a depth of $850 \mathrm{~cm}$ starts with a relatively lower $\delta^{18} \mathrm{O}$ value 
Table 2. Stable isotope data on G. menardii tests and its abundance (count/gram) at DSDP Sites.

\begin{tabular}{|c|c|c|c|c|c|c|c|c|c|}
\hline \multirow{2}{*}{$\begin{array}{l}\text { Depth } \\
\mathrm{cm}\end{array}$} & \multicolumn{3}{|c|}{ Site 241} & \multicolumn{3}{|c|}{ Site 219} & \multicolumn{3}{|c|}{ Site 220} \\
\hline & $\delta^{13} \mathrm{C}$ & $\delta^{18} \mathrm{O}$ & $\mathrm{C} / \mathrm{gm}$ & $\delta^{13} \mathrm{C}$ & $\delta^{18} \mathrm{O}$ & $\mathrm{C} / \mathrm{gm}$ & $\delta^{13} \mathrm{C}$ & $\delta^{18} \mathrm{O}$ & $\mathrm{C} / \mathrm{gm}$ \\
\hline 25 & 1.37 & 0.86 & 85 & $1 \cdot 37$ & -0.67 & 641 & - & - & - \\
\hline 50 & $1 \cdot 36$ & 0.65 & 85 & $1 \cdot 37$ & -0.09 & 170 & $2 \cdot 11$ & 0.70 & 28 \\
\hline 75 & 1.25 & 0.76 & 100 & 1.86 & 0.62 & 274 & 1.85 & 0.95 & 72 \\
\hline 100 & 1.42 & 0.41 & 89 & 1.67 & 0.36 & 367 & $1 \cdot 58$ & 0.69 & 49 \\
\hline 125 & 1.47 & 0.96 & 114 & 1.73 & $-0-05$ & 425 & $1 \cdot 60$ & -0.16 & 109 \\
\hline 150 & 1.49 & 0.73 & 67 & $1 \cdot 33$ & 0.52 & 86 & - & - & 12 \\
\hline 175 & $1 \cdot 34$ & 0.72 & 56 & $1 \cdot 25$ & -0.55 & 382 & 1.64 & -0.07 & 46 \\
\hline 200 & $1 \cdot 29$ & 0.18 & 93 & $1 \cdot 19$ & 0.17 & 349 & 1.69 & $0-06$ & 9 \\
\hline 225 & 1.02 & 0.47 & 104 & $1 \cdot 40$ & -0.28 & 175 & 1.80 & 0.54 & 20 \\
\hline 250 & 1.06 & $0-21$ & 153 & $1 \cdot 11$ & -0.58 & 650 & $1 \cdot 29$ & 0.16 & 77 \\
\hline 275 & $1 \cdot 29$ & -0.21 & 79 & $1 \cdot 13$ & -0.62 & 548 & 1.47 & -0.25 & 11 \\
\hline 300 & 1.25 & 0.24 & 64 & 1.18 & 0.19 & 336 & $1 \cdot 13$ & -0.73 & 48 \\
\hline 325 & 1.43 & 0.77 & 49 & $1 \cdot 13$ & 0.25 & 326 & $1 \cdot 35$ & 0.58 & 100 \\
\hline 350 & $1 \cdot 29$ & 0.29 & 134 & $1 \cdot 16$ & 0.38 & 473 & 1.46 & 0.52 & 81 \\
\hline 375 & $1 \cdot 30$ & 0.49 & 19 & 1.04 & 0.22 & 607 & $1 \cdot 14$ & 0.75 & 283 \\
\hline 400 & $1 \cdot 28$ & 0.76 & 123 & 1.22 & 0.36 & 408 & $1 \cdot 32$ & 0.77 & 115 \\
\hline 425 & $2 \cdot 17$ & -0.31 & 163 & $1 \cdot 22$ & -0.28 & 90 & 1.23 & 0.96 & 216 \\
\hline 450 & $1 \cdot 30$ & $0-18$ & 97 & 1.33 & -0.47 & 206 & 1.42 & -0.17 & 78 \\
\hline 475 & $1 \cdot 34$ & 0.61 & 82 & 1.38 & -0.37 & 163 & 1.52 & 0.72 & 7 \\
\hline 500 & 1.46 & 0.51 & 76 & 1.25 & 0.37 & 193 & 1.59 & -0.71 & 137 \\
\hline 525 & $1 \cdot 23$ & 0.67 & 91 & 1.62 & 0.45 & 330 & $1 \cdot 27$ & $1 \cdot 11$ & 54 \\
\hline 550 & 1.51 & $0-01$ & 107 & 0.99 & 0.18 & 662 & $1 \cdot 29$ & $0-47$ & 33 \\
\hline 575 & 1.43 & $0-46$ & 119 & 1.53 & $0-46$ & 138 & $1 \cdot 21$ & 0.11 & 286 \\
\hline 600 & $1 \cdot 32$ & $0-81$ & 112 & $1 \cdot 36$ & $0-02$ & 352 & 1.03 & $0-00$ & 1 \\
\hline 625 & 1.45 & $0-85$ & 74 & 1.02 & -0.45 & 569 & 1.08 & $0-65$ & 50 \\
\hline 650 & 1.49 & $0-60$ & 117 & $0-91$ & -0.60 & 571 & 1.40 & $0-02$ & 9 \\
\hline 675 & $1 \cdot 39$ & 0.31 & 79 & $1 \cdot 14$ & -0.37 & 498 & $1 \cdot 16$ & 0.36 & 38 \\
\hline 700 & 1.25 & 0.80 & 90 & 1.60 & 0.18 & 399 & - & - & 0 \\
\hline 725 & 1.05 & 0.70 & 99 & 1.51 & 0.51 & 173 & 1.51 & 0.13 & 2 \\
\hline 750 & $1 \cdot 31$ & 0.20 & 81 & $1 \cdot 13$ & 0.49 & 288 & 1.59 & $0-37$ & 0 \\
\hline 775 & 1.38 & 0.76 & 67 & 1.35 & 0.13 & 525 & 1.20 & $0-64$ & 109 \\
\hline 800 & 1.35 & $1-01$ & 78 & 1.08 & -0.77 & 673 & $1 \cdot 27$ & -0.23 & 77 \\
\hline 825 & 1.13 & 0.19 & 79 & $1 \cdot 10$ & -0.30 & 707 & 0.88 & 0.67 & 78 \\
\hline 850 & 1.08 & $0-01$ & 48 & $1 \cdot 14$ & $0-32$ & 183 & 107 & 0.38 & 48 \\
\hline 875 & 1.40 & 0.28 & 57 & $1 \cdot 15$ & $0-44$ & 187 & $1 \cdot 14$ & $1 \cdot 18$ & 17 \\
\hline
\end{tabular}

and shows a higher value at $800 \mathrm{~cm}$ level. From this depth to about $425 \mathrm{~cm}$, the curve shows a slight trend towards lower values. It is succeeded by an enrichment in $\delta^{18} \mathrm{O}$ up to a depth of $300 \mathrm{~cm}$. At $275 \mathrm{~cm}$ level depletion in $\delta^{18} \mathrm{O}$ occurs followed by a steady enrichment till $25 \mathrm{~cm}$.

4.1.2 Carbon isotopes: The carbon isotope ratios also show cyclic variations with a low amplitude ranging usually from 1.51 to $1.02 \%$ with a striking maxima of $2.17 \%$ at $425 \mathrm{~cm}$ depth (figure 2). From the $875 \mathrm{~cm}$ level upwards a relative depletion in $\delta^{13} \mathrm{C}$ values is observed up to a depth of $700 \mathrm{~cm}$, above which a slight enrichment occurs with a somewhat constant trend (with an average value of $1.39 \%$ in this interval) up to $450 \mathrm{~cm}$. At $425 \mathrm{~cm}$ a sharp maximum of $\delta^{13} \mathrm{C}(2 \cdot 17 \%)$ occurs succeeded by a depletion 


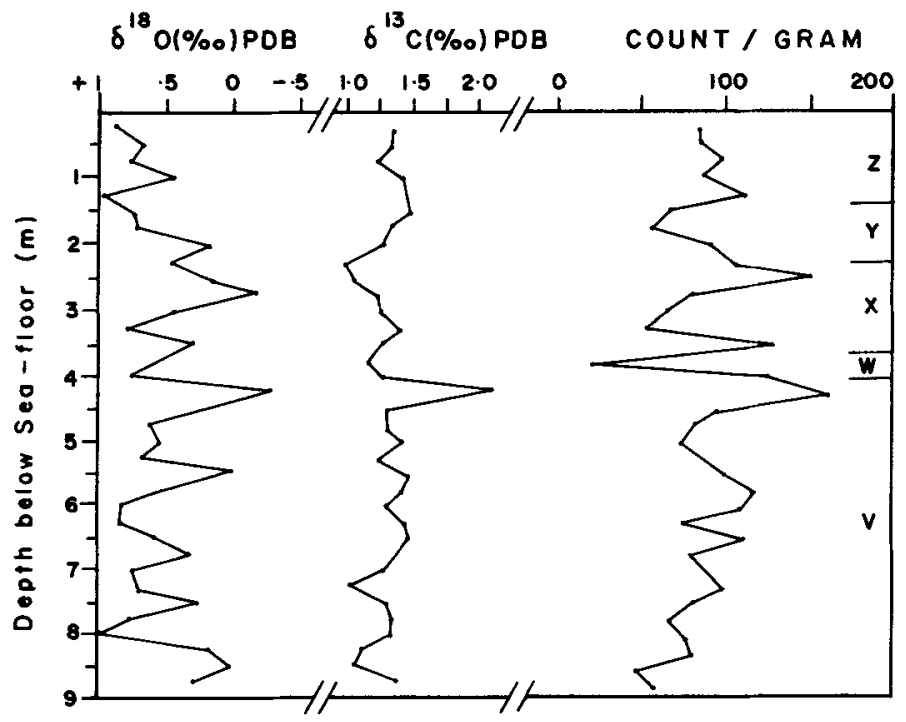

Figure 2. The $\delta^{18} \mathrm{O}(\%) \mathrm{PDB}$ and $\delta^{13} \mathrm{C}(\%)$ PDB depth profiles of $G$. menardii and its abundance distribution at DSDP Site 241 (V - Sangamon interglacial; W - Early Wisconsin glacial; $\mathbf{X}$ - Middle Wisconsin interstadial; $\mathbf{Y}$ - Main Wisconsin glacial and $\mathbf{Z}$ - Post glacial periods).

at $400 \mathrm{~cm}(1.28 \%)$. The decrease in $\delta^{13} \mathrm{C}$ values continues further till a depth of $225 \mathrm{~cm}$, where it attains a value of $1.02 \%$. Above this depth a general gradual enrichment in heavier isotope is observed.

\subsection{Core 219}

4.2.1 Oxygen isotopes: At $25 \mathrm{~cm}$ depth (the $\mathrm{Z}$ zone, post glacial) $\delta^{18} \mathrm{O}$ has a negative value. At this site $\delta^{18} \mathrm{O}$ values range between -0.77 and $0.62 \%$ and the curve (figure 3 ) exhibits uniform cyclicity with somewhat equal amplitude between maxima and minima values from its mean position $\left(\delta^{18} \mathrm{O}=0.005 \%\right)$. Significant enrichment of $\delta^{18} \mathrm{O}$ occurs at depths of $875,750-725,575-500$ and $400-300 \mathrm{~cm}$. Upwards from the $250 \mathrm{~cm}$ level up to $75 \mathrm{~cm}$ there is a general increase in the heavier isotope with two sharp 'low' peaks at $175 \mathrm{~cm}$ and $125 \mathrm{~cm}$ (less intensity) corresponding to W (Early Wisconsin) and late X (Middle Wisconsin) zones respectively. At depths of $800,650,450,275-250$, 175 and $25 \mathrm{~cm}$ (corresponding to $\mathrm{Z}$, post glacial) depletion in $\delta^{18} \mathrm{O}$ is observed. The dissimilarity between the $\delta^{18} \mathrm{O}$ enrichment and depletion peaks is that the former is much wider than the latter.

4.2.2 Carbon isotopes: The $\delta^{13} \mathrm{C}$ stratigraphy (figure 3) shows more pronounced cycles of enrichment and depletion than those evinced at Site 241 which records a smaller part of the Pleistocene than the present one. The $\delta^{13} \mathrm{C}$ values range between 0.99 and $1.86 \%$ (mean 1.31\%). A quite significant depletion between $875 \mathrm{~cm}$ and $750 \mathrm{~cm}$ (mean $1.2 \%$ ) is followed by an alternation of three conspicuous enrichment $(725-700,575$ and $525 \mathrm{~cm})$ and two depletion $(650$ and $550 \mathrm{~cm}$ ) peaks. From $500 \mathrm{~cm}$ up to a depth of $150 \mathrm{~cm}$ a wide 'valley' of depletion exists. From 175 to $75 \mathrm{~cm}$ there is a steady enrichment in the heavier isotope of carbon. 


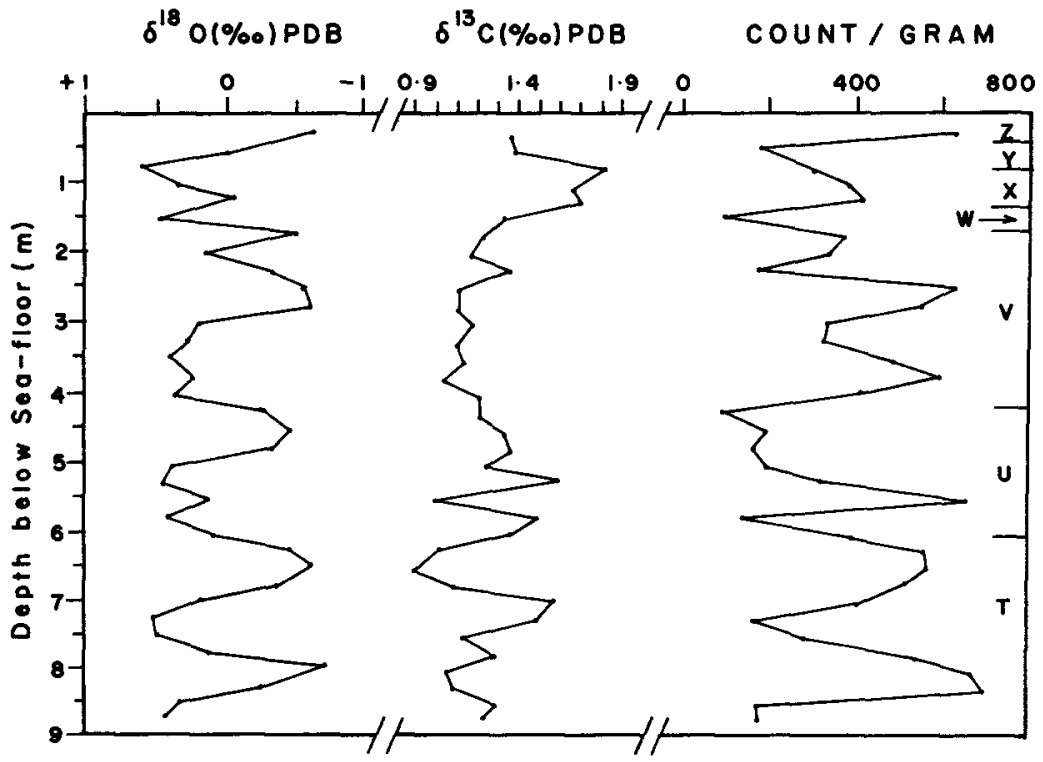

Figure 3. The $\delta^{18} \mathrm{O}(\%)$ PDB and $\delta^{13} \mathrm{C}(\%)$ PDB depth profiles of $G$. menardii and its abundance distribution at DSDP Site 219 (T - Yarmouth interglacial; U - Illinoian glacial; $\mathbf{V}$ - Sangamon interglacial; $\mathbf{W}$ - Early Wisconsin glacial; $\mathbf{X}$ - Middle Wisconsin interstadial; $\mathbf{Y}$ - Main Wisconsin glacial and $\mathbf{Z}$ - Post glacial periods).

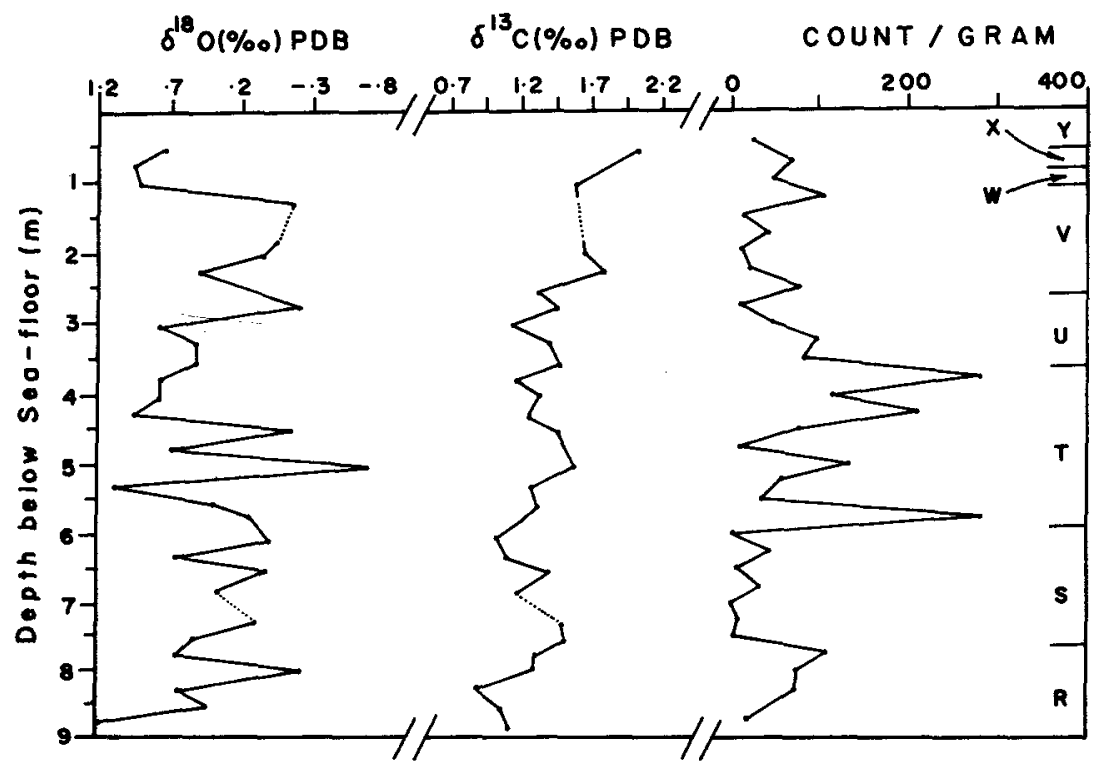

Figure 4. The $\delta^{18} \mathrm{O}(\%) \mathrm{PDB}$ and $\delta^{13} \mathrm{C}(\%)$ PDB depth profiles of $G$. menardii and its abundance distribution at DSDP Site 220 (R-Aftonian interglacial; S-Kansan glacial; $\mathbf{T}$-Yarmouth interglacial; $\mathbf{U}$-Illinoian glacial; $\mathbf{V}$-Sangamon interglacial; $\mathbf{W}$ - Early Wisconsin glacial; $\mathbf{X}$ - Middle Wisconsin interstadial and $\mathbf{Y}$ - Main Wisconsin glacial periods). 


\subsection{Core 220}

4.3.1 Oxygen isotopes: Due to the absence/paucity of $G$. menardii at 700 and $150 \mathrm{~cm}$ levels analyses could not be carried out for samples from these levels. Table 1 shows the presence of $12 \mathrm{G}$. menardii tests at $150 \mathrm{~cm}$ level and the absence of the same at $750 \mathrm{~cm}$ level in the samples for taxonomic/statistical analysis (Sarkar 1991; Sarkar and Guha 1993). While the additional sample, disintegrated for isotopic analysis did not provide adequate $G$. menardii tests at $150 \mathrm{~cm}$ level, the required number of tests for the analysis could be isolated from samples at $750 \mathrm{~cm}$. Though no planktonic foraminifera were present in the $1 \mathrm{gm}$ sample at $600 \mathrm{~cm}$ depth used for statistical analysis, a larger sample at the same level yielded about $0.1 \mathrm{mg}$ (1 test) of $G$. menardii, sufficient for isotopic analysis by the cold finger method. A cyclicity with sharp positive and negative peaks is a characteristic feature of $\delta^{18} \mathrm{O}$ curve at this site (figure 4). The $\delta^{18} \mathrm{O}$ values range from -0.71 to $1.18 \%$ (mean $0.4 \%$ ). Maximum enrichment of heavier isotope takes place at $875 \mathrm{~cm}$ depth followed by a decrease up to the $800 \mathrm{~cm}$ level. From 775 to $550 \mathrm{~cm}$ levels a slight enrichment (mean $0.32 \%$ ) is observed before it reaches one of its maxima at $525 \mathrm{~cm}$. Between 500 and $450 \mathrm{~cm}$, two closely depletion (negative) peaks occur followed by an enrichment from 425 to $300 \mathrm{~cm}$. Above these levels up to $100 \mathrm{~cm}$, the curve shows lighter values followed by a narrow zone of enrichment in $\delta^{18} \mathrm{O}$.

4.3.2 Carbon isotopes: The average $\delta^{13} \mathrm{C}$ value at Site 220 is found to be $1.38 \%$, the maxima and minima being 2.1 and $0.88 \%$ respectively (figure 4). From the $875 \mathrm{~cm}$ level the curve starts with a decreasing trend of $\delta^{13} \mathrm{C}$ up to $825 \mathrm{~cm}$, from where a gradual enrichment in heavier carbon isotope occurs till a depth of $725 \mathrm{~cm}$. Lower carbon isotope value is observed around a depth of $725 \mathrm{~cm}$. Further upwards a slight enrichment in heavier isotopes takes place and a monotonous trend is observed between 600 and $225 \mathrm{~cm}$ levels with an average value of $1.34 \%$. A somewhat steady enrichment in $\delta^{13} \mathrm{C}$ value is observed at levels above $225 \mathrm{~cm}$.

\section{Discussion}

Based on oxygen isotope stratigraphy the last glacial maximum (LGM) at Site 241 (figure 2) has been located at $125 \mathrm{~cm}$, where the $\delta^{18} \mathrm{O}$ shows a strong positive peak $(0.96 \%$ ). Considering the LGM age to be $18 \mathrm{ka}$ (Prell et al 1980$)$ the average sedimentation rate at this site during the post-glacial stage appears to be $6.9 \mathrm{~cm} / \mathrm{ka}$. Oxygen isotope stage 5 (last interglacial, $125 \mathrm{ka}$ ) at this site has been located at $425 \mathrm{~cm}$ with the highest negative $\delta^{18} \mathrm{O}$ value $(-0.31 \%)$ indicating that sediment accumulation rate during the glaciation was around $2.8 \mathrm{~cm} / \mathrm{ka}$. Though intense upwelling is associated with increased polar cooling and formation of more AABW (Keller and Barron 1987; Gupta and Srinivasan 1990), upwelling in the western Arabian Sea has been found to be linked with the summer southwest monsoon (Dietrich 1973; Prell and Streeter 1982; Prell and Van Campo 1986; Prell and Niitsuma 1988). Since the southwest monsoon was strong during the interglacial periods and weak during the glacial periods (Prell 1978; Prell et al 1980; Prell and Curry 1981; Prell and Kutzbach 1987) the upwelling intensity would also be strong during interglacial periods. As upwelling enhances productivity in general, one would expect a higher sedimentation rate during deglaciation. This is observed in the sedimentation rates calculated above. These observations 
are also in agreement with the abundance variations of $G$. menardii whose maximum occurs during the last interglacials $(425 \mathrm{~cm}, 125 \mathrm{ka})$. The abundance is also significantly low during LGM $(125 \mathrm{~cm}, 18 \mathrm{ka})$ : the transition from $V$ to $Z$ zones. Below the $425 \mathrm{~cm}$ level, the upper limit of $\mathrm{V}$ zone, this site exhibits 4 cycles of oscillations in $\delta^{18} \mathrm{O}$ values. However, in this part of the core there is a discernible trend towards a cooler climate $850 \mathrm{~cm}$ level excepted. This corresponds well with the frequency oscillation of G. menardii within this zone (V) at this site.

The GIA for the northern Indian Ocean at stations SK-20-185 $\left(10^{\circ} \mathrm{N}, 71^{\circ} 50^{\prime} \mathrm{E}\right.$, $2523 \mathrm{~m})$ and SK-20-186 $\left(0^{\circ} 2^{\prime} \mathrm{S}, 68^{\circ} 30^{\prime} \mathrm{E}, 3564 \mathrm{~m}\right)$ with a sampling interval of 2 to $5 \mathrm{~cm}$ is of the order of $2 \cdot 12$ to $2.28 \%$ (Sarkar 1989). But at Site 241 , the amplitude is about 1 to $1 \cdot 3 \%$. For this reduction in GIA one may consider the following. In general the GIA has two components: temperature and ice volume. These two, during an interglacial-glacial transition, act in the same direction to change the foraminiferal $\delta^{18} \mathrm{O}$. But in the case of an upwelling-prone zone like the Somali coast (near Site 241) the GIA may be reduced due to interglacial strong summer monsoon, intense upwelling and the resultant decrease in surface temperature by $2-3^{\circ} \mathrm{C}$. On the contrary during glacial periods upwelling is almost absent due to the weakening of the southwest monsoon and a consequent decrease in surface cooling. This acts in the opposite direction to the other two factors considered above. A second possibility for the reduction in GIA could be the fact that the coarser sampling interval of $25 \mathrm{~cm}$ might have missed some peaks in the $\delta^{18} \mathrm{O}$ oscillation. Furthermore $G$. menardii being a deep-dwelling species probably recorded a $\delta^{18} \mathrm{O}$ pulse of much less magnitude (Sarkar et al 1990).

In northwestern Indian Ocean, Prell and Niitsuma (1988) noted an upwellinginduced higher biotic productivity. During the last interglacial $(125 \mathrm{ka})$ the southwest monsoon was very strong which led to an intense upwelling and increased productivity. A clear peak has been observed in the $\delta^{13} \mathrm{C}$ corresponding to this period $(425 \mathrm{~cm})$. During the last glaciation the southwest monsoon was weak, therefore the productivity was also weaker leading to lower $\delta^{13} \mathrm{C}$ values in general.

Though in the above paragraph, variation in the $\delta^{13} \mathrm{C}$ has been interpreted in terms of monsoon-induced changes in upwelling and resultant productivity, another factor may be considered. In the ocean the mixed layer (euphotic zone) is enriched in $\delta^{13} \mathrm{C}$ due to preferential removal of ${ }^{12} \mathrm{C}$ by organisms. In the deeper ocean (up to about $1000 \mathrm{~m}$ depth) the organic matter gets oxidized and $\mathrm{CO}_{2}$ depleted in ${ }^{13} \mathrm{C}$ is released into the ocean. As a result when upwelling takes place the ${ }^{12} \mathrm{C}$ enriched water is brought up and gets mixed with the surface water decreasing its $\delta^{13} \mathrm{C}$ values. This mixing acts in the opposite direction to that of productivity as far as the $\delta^{13} \mathrm{C}$ of foraminiferal calcite is concerned. Thus the resultant variation is a combination of these two factors. The final result depends upon the stronger of the two factors. In this study it appears that the productivity effect has been stronger at the $125 \mathrm{ka}$ level $(425 \mathrm{~cm})$.

At Site 219 , from the array of $\delta^{18} \mathrm{O}$ values, the LGM may be fixed at a depth of $75 \mathrm{~cm}$. Thus the average sedimentation rate for this period (last deglaciation) works out to be $4 \cdot 2 \mathrm{~cm} / \mathrm{ka}$, consistent with the results of Whitmarsh et al $(1974, \mathrm{p} .45)$. The last interglacial maximum may be placed at a depth of $175 \mathrm{~cm}$ where $\delta^{18} \mathrm{O}$ is more towards the negative side. Therefore, during the Wisconsin glaciation the sedimentation rate was approximately $0.9 \mathrm{~cm} / \mathrm{ka}$. For the above calculation the ages of LGM and the last interglacial maxima have been considered to be $18 \mathrm{ka}$ and $125 \mathrm{ka}$ respectively. In the 
entire core there are six peaks in $\delta^{18} \mathrm{O}$ (towards the negative side) at $800,650,450,275$ and $175 \mathrm{~cm}$ depths which probably represent major and minor 5 interglacial periods. Comparing these peaks with those given in the SPECMAP data (Imbrie et al 1984) the approximate ages for these peaks are $500,400,320,210$ and $125 \mathrm{ka}$ respectively. The bottom of the record $(875 \mathrm{~cm})$ corresponds to about $630 \mathrm{ka}$. These age data can be corroborated by the sedimentation rate for the studied sections as given by Whitmarsh et al $(1974$, p. 45). The GIA value is of the order of $1.4 \%$ less than the reported value of around $2 \%$ for sites near Site 219 (Sarkar 1989). The plausible explanation for such reduction has been discussed in the preceding section on Site 241.

The oscillation in the $\delta^{18} \mathrm{O}$ curve at Site 219 (figure 2) is in good agreement with the frequency curve of $G$. menardii, i.e., abundance peaks during interglacial periods are indicated by negative $\delta^{18} \mathrm{O}$ peaks and vice-versa. However this agreement is disturbed at levels between 475 and $300 \mathrm{~cm}$. This anomaly is possibly due to coarse sampling.

The $\mathrm{CaCO}_{3}$ percentage in Core 219 at $820,660,480,340,188,139$ and $38 \mathrm{~cm}$ are 70 , $73,71,60,58,52$ and $68 \%$ respectively (Bode 1974 ). The productivity increases during interglacial periods with strong summer monsoons. The levels near the above mentioned depths have produced assemblages which show good correlation of high abundance of $G$. menardii and depleted $\delta^{18} \mathrm{O}$ values with high carbonate percentage.

Variations in $\delta^{13} \mathrm{C}$ are generally positively correlated with $\delta^{18} \mathrm{O}$. At this site at many levels it appears that the water mass was characterized by a general depletion of heavier carbon isotopes. It appears that out of two factors viz., productivity and mixing, the latter controls the $\delta^{13} \mathrm{C}$ variations at this site. During interglacial periods when the southwest monsoon was vigorous, the deepening of the mixed layer would have depleted the surface water in $\delta^{13} \mathrm{C}$ to some extent. Thus the negative peaks in $\delta^{18} \mathrm{O}$ (interglacials) correspond to lower $\delta^{13} \mathrm{C}$ values. Besides, below $150 \mathrm{~cm}$ depth in this core, the abundance of $G$. menardii is also negatively correlated with $\delta^{13} \mathrm{C}$. This suggests that despite the increased productivity, $\delta^{13} \mathrm{C}$ values were reduced during interglacial periods, indicating the effect of deepening of the mixed layer.

Since the sedimentation rate was very low, the $25 \mathrm{~cm}$ sampling interval at Site 220 corresponds to a wider time interval than at the other two sites. Moreover, the inadequacy of faunal record at some levels has added to the problem of precisely deciphering the cyclicity of $\delta^{13} \mathrm{C}$ values and the assignment of isotopic age (using SPECMAP time scale) of the core which should have recorded 12 major and minor interglacial periods. Based on SPECMAP time scale, if the age of the maximum negative peak of $\delta^{18} \mathrm{O}$ at $500 \mathrm{~cm}$ depth is assigned at about $730 \mathrm{ka}$, the rate of sedimentation works out to be $0.7 \mathrm{~cm} / \mathrm{ka}$, consistent with that of Whitmarsh et al (1974). As at Site 219, there exists an overall similarity between the $G$. menardii abundance and $\delta^{18} \mathrm{O}$ (negative) peaks.

The $\delta{ }^{13} \mathrm{C}$ curve at Site 220 does not present sharp fluctuations like those observed at Sites 241 and 219. As this site location is nearer (about $320 \mathrm{~km}$ ) to Site 219, the earlier observation has been corroborated. Thus in this region the $\delta^{13} \mathrm{C}$ variations were more likely to be controlled by the mixing of deep waters, rather than productivity.

Though a general correspondence can be deciphered among the abundance of G. menardii at V and $\mathrm{T}$ zones (Sangamon and Yarmouth interglacials) and enrichment of $\delta^{13} \mathrm{C}$ values at this site, it is observed that at other levels such agreement is not fully discernible due to constraints already noted. 


\section{Conclusions}

The GIA at Sites 241,219 and 220 is of the order of $1 \cdot 2,1.4$ and $1.9 \%$ respectively. As Site 241 is an upwelling-prone zone, the GIA might have been decreased due to the mixing of cooler upwelled waters during the period of enhanced southwest monsoon. The last glacial and interglacial maxima (18 $\mathrm{ka}$ and $125 \mathrm{ka}$ respectively) could be recognized in DSDP Cores 241 and 219 with some precision. Comparing Cores 219, 220 and 241 with the SPECMAP time scale (Imbrie et al 1984) the 'warming' peaks in the $\delta^{18} \mathrm{O}$ curve could be correlated with the different 'isotopic ages'. Based on the $\delta^{18} \mathrm{O}$ stratigraphy the changes in sediment accumulation rates during glacial and interglacial periods at different levels in these cores could be worked out. Ericson zones corresponding to changes in $G$. menardii abundance are generally in good agreement with the oxygen isotope stratigraphy of these sites.

The oscillation in $\delta^{13} \mathrm{C}$ stratigraphy in Core 241 corresponds to the changes in surface productivity induced by fluctuations in the southwest monsoon intensity during the interglacial periods. The $\delta^{13} \mathrm{C}$ variations at Sites 219 and 220 were not due, to changes in surface productivity only, but resulted from the vertical mixing of deep waters as well.

\section{Acknowledgements}

The DSDP authorities, Scripps Institution of Oceanography, University of California, USA provided the samples. B L K Somayajulu, S K Bhattacharya and R Ramesh of PRL, Ahmedabad rendered opportunities and guidance for stable isotope analysis at PRL, and RR critically reviewed an earlier version of the manuscript. M S Srinivasan of BHU, Varanasi made some important suggestions while reviewing the manuscript. IIT Kharagpur authorities provided the necessary laboratory facilities. Financial support came from CSIR in the form of a research grant [No. 9/81/(219)/94-EMR-1].

\section{References}

Ahmad S M and Labeyrie L D 1994 Glacial to Holocene $\delta^{13} \mathrm{C}$ variations in intermediate depth water masses of north Indian Ocean; Geo-Marine Lett. 14 36-40

Berger W H 1968 Planktonic foraminifera: selective solution and paleoclimatic interpretation; Deep-Sea Res. $1531-43$

Bode G W 1974 Carbon and carbonate analyses, Leg 23; In: Initial reports of DSDP. (eds) R B Whitmarsh, O E Weser and D A Ross et al (Washington: US Govt. Print. Office), 23 1131-1135

Boersma A 1978 Foraminifera; In: Introduction to Marine Micropalaentology, (eds) B U Haq and A Boersma (New York: Elsevier) p. 376

Bowen R 1966 Palaeotemperature analysis, methods in Geochemistry and Geophysics 2 (Elsevier Pub. Co.) p. 265

Chakraborty S 1993 Environmental significance of isotopic and trace elemental analysis in banded corals; PhD Thesis, M S Univ. of Baroda, p. $119+23$

Dietrich $\mathrm{G} 1973$ The unique situation in the environment of the Indian Ocean; In: The Biology of the Indian Ocean, (ed.) B Zeitzschel (New York: Springer-Verlag) 1-6

EmilianiC 1954 Depth habitats of some species of pelagic foraminifera as indicated by oxygen isotope ratios; Am. J. Sci. 252 149-158

Emiliani C 1966 Palaeotemperature analysis of Caribbean cores p. 6304-8 and p. 6304-9 and a generalized temperature curve for the past 425,000 years; J. Geol. 74 109-126 
Erez J and Luz B 1983 Experimental palaeotemperature equation for planktonic foraminifera; Geochim. et Cosmochim. Acta 47 1025-1031

Ericson D B, Ewing M and Wollin G 1964 The Pleistocene epoch in deep-sea sediments; Science 146 123-132

Ericson D B, Ewing M, Wollin G and Heezen B C 1961 Atlantic deep-sea sediment cores; Geol. Soc. Am. Bull. 72 193-286

Ericson D B and Wollin G 1968 Pleistocene climates and chronology in deep sea sediments; Science 162 $1227-1234$

Guha A K and Sarkar A 1990 Planktonic foraminifera from DSDP Site 241 in Somali Basin, northwestern Indian Ocean; J. Pal. Soc. India 35 169-175

Gupta A K and Srinivasan M S 1990 Response of northern Indian Ocean deep-sea benthic foraminifera to global climates during Pliocene-Pleistocene; Marine Micropaleontology 16 77-91

Imbrie J, Hays J D, Mortinson DG, MacIntyre A, Mix A C, Morley J J, Pisias N G, Prell W L and Shackleton N J 1984 The orbital theory of Pleistocene climate: Support from a revised chronology of the marine $\delta^{18} \mathrm{O}$ record; In: Milankovitch and Climate Part I, (eds) J Imbrie, J Hays, G Kukla and B Saltzman (Dordrecht: D. Reidel Pub. Co.) 269-305

Keller G and Barron J A 1987 Paleodepth distribution of Neogene deep-sea hiatuses; Paleoceanography. $2697-713$

Kennett J P 1986 Miocene to Early Pliocene oxygen and carbon isotopic stratigraphy in the southwest Pacific; In: Initial Repts., DSDP 90 1383-1412

Prell W L 1978 Glacial-interglacial variability of monsoon upwelling: Western Arabian Sea; In: Conf. Evolution of Planetary Atmosphere and Climatology of the Earth. Centre nationa d' Etude Spatiales, Nice, 149-156

Prell W L and Curry W B 1981 Faunal and isotopic indices of monsoonal upwelling: Western Arabian Sea; Oceanological Acta $491-98$

Prell W L, Huston W H, Williams D F, Be A W H, Geitzenauer W and Molfinos B 1980 Surface circulation of the Indian Ocean during the last glacial maximum approximately 18,000 yrs BP; Quat. Res. 14 309-336

Prell W L and Kutzbach J E 1987 Monsoon variability over the past 150,000 years; J. Geophys. Res. 92 8411-8425

Prell W L and Streeter H F 1982 Temporal and spatial patterns of monsoonal upwelling along Arabia: A modern analogue for the interpretation of Quaternary SST anomalies; J. Mar. Res. 40 143-155

Prell W L and Niitsuma N 1988 Milankovitch and monsoons; Nature (London) 331 663-664

Prell W L and Van Campo E 1986 Coherent response of Arabian Sea upwelling and pollen transport to late Quaternary monsoonal winds; Nature (London) 323 526-528

Sarkar Anindya 1989 Oxygen and carbon isotopes in Indian Ocean sediments and their paleoclimatic implications. PhD Thesis. Gujarat University, Ahmedabad, p. 164

Sarkar Ashish 1991 Pleistocene planktonic foraminifera from DSDP Sites 219, 220, 235 and 241 in the northern Indian Ocean and their paleoclimatic implications. PhD dissertation, IIT, Kharagpur, p. 152

Sarkar A and Guha A K 1993 Paleoceanographic implications of planktonic foraminiferal abundance at DSDP Sites 219, 220 and 241 - An approach based on paleontologic time series; J. Geol. Soc. India 41 $397-416$

Sarkar A, Ramesh R, Bhattacharya S K and Rajagopalan G 1990 Oxygen isotopic evidence for a stronger winter monsoon current during the last glaciation; Nature (London) 343 549-551

Simpson E S W and Schlich R et al 1974 Initial reports of the deep-sea drilling project, (Washington: US Govt. Printing Office) XXV p. $x x+884$

Singh A D and Srinivasan M S 1993 Quaternary climatic changes indicated by planktonic foraminifera of northern Indian Ocean; Curr. Sci. $64908-915$

Srinivasan M S and Chaturvedi S N 1990 Neogene paleoceanographic events in the tropical Indian Ocean: Evidence from quantitative planktonic foraminiferal analyses and isotopic record; In: Pacific Neogene Events: Their timing, nature and inter-relationship (ed.) R Tsuchi, Univ. of Tokyo Press 65-73

Srinivasan M S and Singh A D 1991 Planktonic foraminiferal evidence for the Neogene paleoceanographic changes in the Indian Ocean; The annual technical meeting on IGCP-246 (Thailand: Chiang Mai University) 179-205

Whitmarsh R B, Weser O E and Ross D A et al 1974 Initial reports of the deep-sea drilling project, (Washington: US Govt. Printing Office) XXIII p. 1180 